\title{
Making space for plural ontologies in fisheries governance: Ireland's disobedient offshore islands
}

\author{
Ruth Brennan ${ }^{1}$ D \\ Received: 10 November 2020 / Accepted: 28 December 2021 / Published online: 29 January 2022 \\ (c) The Author(s) 2022
}

\begin{abstract}
This paper contributes to the growing body of literature that engages with ontological scholarship on fisheries management and governance, and more generally, to debates on environmental governance. It argues that fisheries governance is an ontological challenge that raises questions of culture, equity, legitimacy and inclusion/exclusion, requiring more contextsensitive and politically aware fisheries governance approaches. By engaging with the concept of political ontology, and drawing from empirical research carried out in Ireland's offshore islands, five ontological assumptions are identified that underpin Irish fisheries governance and management policies and practices and categorised as social-historical, ecological, geographical, technocratic and markets-driven. Articulating and examining these assumptions provide insights into why policy objectives aimed at supporting small-scale fisheries and their communities may, in practice, not be effective when they are operationalised within a governance paradigm designed around the realities of large-scale, full-time, highly mobile and more economically productive operators. Despite the efforts of ontologically disobedient islanders, the enactment of these ontological assumptions into the dominant world of fisheries governance inhibits the emergence of possible worlds that would enact Irish island inshore fisheries through island logics. The paper concludes that the squeeze on Ireland's island inshore fishers is not simply spatial, it is ontological. A dominant fisheries ontology has been created by the interplay of ontological assumptions. This dominant ontology undermines the State's critical policy to maintain and manage Irish fisheries as a public resource in order to avoid the concentration of fishing opportunities into the hands of large and powerful fishing interests.
\end{abstract}

Keywords Ontology $\cdot$ Political ontology $\cdot$ Environmental governance $\cdot$ Fisheries governance $\cdot$ Small-scale fisheries . Islands

\section{Introduction}

Despite calls for better integration of social, economic and cultural considerations in fisheries management (Urquhart et al. 2013), fisheries policy instruments continue to frame fisheries governance as predominantly a technocratic challenge (Johnsen 2014; FAO 2021). Fisheries management approaches tend to be narrowly focussed on fisheries biology and economic activities, while ignoring the politicised nature of fisheries (Nightingale 2013; Donkersloot and Menzies 2015; Bennett 2019; McCormack and Forde 2020) and failing to account for social and emotional connections between fishing communities and the sea (Olson 2010; Nightingale

Ruth Brennan

ruth.brennan@tcd.ie

1 Trinity Centre for Environmental Humanities, Trinity College Dublin, Dublin 2, Ireland
2011; Nightingale 2013; Rossiter et al. 2015; Boucquey et al. 2016). The proposed, and highly technical, European Fisheries Control Regulation ${ }^{1}$ reinforces this technocratic and apolitical framing of fisheries and the marine space. Yet, the ocean can be understood as a "constantly shifting ontological space" (Boucquey et al. 2016, 10) and provides a productive context "to attend not just to ontologies enacted, but also...to the textures on the margins" (Law and Lien 2013, 373). This paper joins the calls for more context-sensitive and politically aware fisheries governance approaches by arguing that fisheries governance should be understood as an ontological challenge that constantly raises questions of culture, equity, legitimacy and inclusion/exclusion. The assumptions underpinning fisheries management policies may privilege certain fisheries 'worlds' or ontologies over others, which risks the marginalisation and possible erasure

\footnotetext{
1 https://www.europarl.europa.eu/meetdocs/2014_2019/plmrep/ COMMITTEES/PECH/PR/2021/01-14/1198377EN.pdf
} 
of those "not quite realised realities" (Law and Lien 2013, 363) that do not conform to dominant fisheries governance approaches. Articulating and examining these assumptions can help to explain why policy objectives aimed at supporting small-scale fisheries and their coastal and island fishing communities may, in practice, not be effective when they are operationalised within a governance paradigm designed around the realities of large-scale, full-time and more economically productive operators.

By ontologies, I mean the different ways we frame (Lakoff 2010) and understand the nature of reality, the actions (performances) that are shaped by the assumptions underpinning these different framings and the various processes of assertion of particular worlds (Sullivan 2017). Engaging with ontological questions requires us to pay attention to how we shape and make the world through the tools, ideas, frameworks and theories that we use to understand it (Mather et al. 2017). The notion that there are choices as to which worlds or ontologies to assert belies the political nature of ontologies: if diverse realities can be enacted, the assertion of some worlds may be privileged over others and different worlds or ontologies may end up "bumping heads" (Mol 2002; Blaser 2013a, 25; Yates et al. 2017). I follow Blaser (2009a), in using the terms 'worlds' and 'ontologies' as synonyms as a key focus of this paper is examining how "ontologies perform themselves into worlds" (Blaser 2009a, 877). The concept of 'political ontology' refers to studies of the conflicts generated by these different worlds-ontologies becoming entangled and struggling to ensure their continued existence, as well as directing attention to the politicised nature of practices and processes that bring these different worlds-ontologies into being (Blaser 2009b). In other words, political ontology asks us to consider the pluriverse as a possibility, to pay attention to how different worlds emerge (a process described as "worlding" by Blaser (2014)) and to critically examine what happens when they meet each other (Blaser and de la Cadena 2018). The attention paid by critical scholars to the social and political dimensions of knowledge construction, and the framings and cultural understandings of environmental phenomena, have laid bare the ways in which powerful interests are supported through the privileging of certain ontologies in producing policyrelevant environmental knowledge (Sullivan 2017) and the technocratic-scientific, apolitical and ahistorical terms in which environmental governance tends to be framed (DePuy et al. 2021). As the empirical data in this paper tell a story of the privileging of certain fisheries worlds to the detriment of others, my ontological analysis is informed by political, historical and socio-cultural contexts and engages with the practical and political challenges involved in embracing ontological pluralism in fisheries governance.

DePuy et al. (2021) have recently engaged ontologically with the concept of environmental governance in the context of land, water and biodiversity. While ontological considerations are evident in some critical scholarship on fisheries management and governance (Olson 2010; A. J. Nightingale 2011; Olson 2011; A. Nightingale 2013; Bresnihan 2016; McCormack 2016; Sønvisen et al. 2017; Bresnihan 2019; McCormack and Forde 2020), it is less usual to see this topic explicitly framed as an ontological challenge (although see St. Martin 2006; Rossiter et al. 2015; Daniels and Mather 2017; St. Martin and Olson 2017; Mather et al. 2017; Neilson and São Marcos 2019). Linking this scholarship is the attention paid to identifying fisheries management policies that follow the market logic of neoliberalism through the assertion of a fishing industry composed of rational, self-interested individuals who compete to extract 'natural resources' for maximum economic profit. For example, St. Martin's (2006) framing of fishers as potential 'communities-at-sea' challenges the more usual depiction of individual, competing fishers in boats and the assumption that fishing communities are located and performed only on land. Nightingale's $(2011,2013)$ work on Scottish inshore fisheries similarly challenges the notion of individual, competing fishers at sea by showing how they cooperate at sea, for example, through dividing up fishing grounds to avoid gear entanglements and exchanging information on weather conditions. The depiction of the "individual fisherman...abstracted from his social and material context and reduced...to homo economicus" has also been challenged in the Irish context (Bresnihan 2016, 121-122). These articulations of 'communities-at-sea' make "an ontological statement about the existence of processes and practices of community in places" (St. Martin and Olson 2017, 128). Olson's earlier $(2010$; 2011) work makes an ontological statement about the materialities of fishing by showing how the conflation of fishers and fishing effort in a single fishing effort variable ignores the different spatial dependencies of different fishers. By mapping fishing dependencies instead of fishing effort, Olson demonstrates how fishing grounds are social and heterogeneous spaces, where "differing worldviews, practices and spatialities" exist amongst and between small-scale fishers and the more economically productive fishers who account for the majority of landings (Olson 2010, 294). This research highlights the risk of uneven and unjust distributional outcomes (St. Martin and Olson 2017) when the practices of one part of the fleet (consisting of fewer, larger, more mobile and economically productive vessels) are assumed to be representative of an entire fishery. Neilson and São Marcos (2019) argue that recognition of a multiplicity of ontologies is necessary to prevent the ontological exclusion, in the name of 'blue growth', of smallscale fishers in the Portuguese Azores Islands. Rossiter et al. $(2015,148)$ call for "ontological and discursive shifts" in fisheries policy and management, in order to provide "conceptual capacities for engagements with marine-spaces' 
ever-assembling, irreducible, multiplicitous, emergent, and contingent natures". In a broader marine governance context, critical scholarship on how marine spatial planning (MSP) is being imagined and enacted has also engaged with the concept of ontologies (see Boucquey et al. 2016; Fairbanks et al. 2018; Boucquey et al. 2019). These authors point to ontological assumptions being made about the spaces and actors that are involved in MSP and the solidification (and potential slippage) of dominant ocean ontologies through the use of ocean data portals that support MSP. Although they do not explicitly refer to ontologies, Brent et al.'s (2018) analysis of the mobilisation of the concept of blue growth to reconfigure the ocean within the EU's rapidly expanding 'blue economy' speaks to the assertion of a particular world, where "the terms of entry into the blue growth party" are not conducive to the processes and practices of the smallscale fishing industry and threaten their survival (Brent et al. 2018, 20). Sønvisen et al. (2017) challenge the Norwegian narrative that enacts a safe and healthy fisher as one who conforms to a body mass index measurement that does not indicate obesity. They show how the regulations directly shape fishers' bodies, as 'obese fishers' cannot obtain the requisite health certificate needed to work on board vessels of a certain size, thus encouraging conformity with a predetermined body mass. McCormack's $(2016,175)$ examination of fisheries quota systems in New Zealand, Iceland and Ireland addresses different ontologies of fish, highlighting "the creativity involved in the emergence of virtual fish and the attendant relegation of nature, and labour, as inconsequential in generating wealth". The consequences of the emergence of the virtual or 'cyborg fish' are also observed by Johnsen (2017).

Building on this research that links ontologies, fisheries governance and marine resource management, and using political ontology as an analytical tool, I draw on ethnographic, qualitative evidence from a case-study of the smallscale fishing industry in Ireland's offshore islands to explore the politicised nature of how different fisheries worlds are enacted, which worlds are (and are not) considered to be legitimate and legible within the fisheries management system and related policy instruments. I consider how the conflicts generated by multiple ontologies-worlds becoming entangled can point to alternative possibilities for fisheries governance and create space for new worlds to emerge (Snyder and St Martin 2015; Boucquey et al. 2019). Following Boucquey et al. (2016) and Blaser (2009b), I show how the stories that depict the performance of multiple ontologies reveal the ontological assumptions underpinning Irish fisheries governance approaches. Probing these ontological assumptions provides insights into how, despite attempts to account for the worlds of small-scale fisheries in Irish fisheries management approaches and policy instruments, the dominant world enacted by those practices and instruments risks subordinating the small-scale fisheries worlds by continuing to reduce these worlds to its own (Blaser 2009b), and, in the process, rendering them invisible (DePuy et al. 2021).

This analysis has relevance beyond the Irish fisheries context as the challenges faced by Ireland's small-scale fishing industry have much in common with small-scale fisheries globally. Shared challenges include difficulties accessing fishing opportunities (in particular, valuable quota controlled stocks); competing with the more powerful medium and large-scale industrial interests for fish stocks and markets; obstacles to participation in fisheries governance (for example, through fish producer organisations who mainly represent medium to large-scale fleets); difficulties making their voices heard in systems that value and privilege high economic output (although small-scale fisheries generally represent the majority of their national fleets in terms of numbers of vessels and fishers, their economic output is dwarfed by that of the larger-scale members of the fleet whose power affords them seats at decision-making tables such as those that manage quota allocations); and being adversely impacted by policies that are designed around the fishing practices and management of larger vessels (Linke and Jentoft 2014; Frangoudes and Bellanger 2017; PascualFernández et al. 2019; Pascual-Fernández et al. 2020; Percy and O'Riordan 2020).

\section{Methods}

I anchor my analysis in ethnographic research undertaken between 2018 and 2020 in ten ${ }^{2}$ of the small-scale fishing communities in Ireland's eighteen inhabited offshore islands, sixteen of which have registered fishing vessels. ${ }^{3}$ Empirical material was collected through analysis of fisheries policy documents and through qualitative research methods, including participant observation in island communities (28 days) and at five fishing industry events; twenty-nine unstructured and semi-structured interviews with islanders, island fishers and fishing industry representatives (such as producer organisations); and six semi-structured interviews with policy-makers and policy-implementers in relevant government departments and State agencies. Grounded theory (Glaser and Strauss 1967; Charmaz 2006) was used to identify emergent themes in the data. Tension points, characterised by contested knowledge and conflict (Flyvbjerg et al.

\footnotetext{
${ }^{2}$ I conducted unstructured and semi-structured interviews with islanders from Arranmore and Inishbofin (Donegal Islands), Inishturk and Clare Island (Mayo Islands), Inishbofin and Inis Oírr (Galway Islands), Bere Island, Cape Clear, Sherkin Island and Heir Island (Cork Islands).

${ }^{3}$ Four of these islands have just one remaining registered vessel.
} 
2012; Flyvbjerg et al. 2016) were sought out throughout the interview and analysis process to help identify potential fisheries worlds that were 'bumping heads', with the aim of creating space for new worlds to become legible and legitimate within Irish fisheries governance. I theorised five ontological assumptions underpinning Irish fisheries governance approaches by using the concept of political ontology (Blaser 2009b) to interrogate emergent themes and tension points.

\section{Case study: small-scale fisheries governance in Ireland's offshore islands}

The Irish fishing industry is divided into pelagic, offshore (or whitefish) and inshore segments. Although the majority of vessels are registered in the inshore sector, the economic value of this sector is vastly exceeded by that of the pelagic and offshore segments (McCormack 2016; Fitzpatrick et al. 2020). Planning and management of the Irish marine environment sits in the Department of Housing, Local Government and Heritage ${ }^{4}$; however, the primary responsibility for fisheries management lies with the Sea Fisheries Policy and Management Division in the Department of Agriculture, Food and the Marine (DAFM). ${ }^{5}$ The State's overall fisheries management goal, as articulated by DAFM, is "to implement national policies, negotiated within the Common Fisheries Policy, that support a long term sustainable seafood industry for Ireland, and to maximise the long term contribution of the seafood industry to the economies of coastal regions". ${ }^{6}$ A "critical policy" of the State is to manage quota-controlled stocks as a public resource to ensure that property rights are not granted to individual operators and so that fishing opportunities are not concentrated into the hands of large fishing interests (DAFM 2016, 1; DAFM 2019, 2). The implementation of the first iteration of the Common Fisheries Policy in 1983 introduced quota shares and catch limits (total allowable catch (TAC)) for individual stocks as fisheries management tools.

Although Ireland has resisted the privatisation of fishing rights encouraged by the EU, so that the national quota belongs to the State, McCormack $(2016,180)$ observes that "this is a tenuous claim given the centralised European management structure; the historic propensity towards TAC and thus national quota - reductions; the perceived political

\footnotetext{
${ }^{4}$ With the formation of a new Irish Government on 27 June 2020, the Department of Housing, Planning and Local Government was renamed the Department of Housing, Local Government and Heritage

${ }^{5}$ In this paper, I use the terms DAFM (Department of Agriculture, Food and the Marine) and the State interchangeably, unless otherwise indicated.

${ }^{6}$ https://www.gov.ie/en/publication/10cc8-sea-fisheries-policymanagement-division/
}

biases in the European annual TAC setting process; and the allegations of inequity in the national distribution of the quota". The Common Fisheries Policy with its quota management regime has profoundly reshaped the ontology of Irish fisheries, as commercial fishing rights for valuable quota-controlled species have shifted away from small ports and fishing communities to four major ports where the larger operators are concentrated. This spatial shift has "transformed a multi-species, multi-gear fishing tradition based on seasonal harvesting into a single-species, single-gear, yearround fishing effort" (McCormack 2016, 188). Irish fisheries management is dominated by an instrumental characterisation of human-nature relationships that is reflected in the broader marine policy context in Ireland. A distinct focus on 'ecosystem goods and services' and 'natural capital' is evident in policy documents such as Ireland's first integrated marine plan in $2015^{7}$ and the more recent National Marine Planning Framework published in June 2021. ${ }^{8}$ This instrumental focus reinforces the productivity-focussed and markets-driven State ontologies (discussed below in the context of fisheries), privileges market rationalities over other ways of understanding human-environment relationships (McCormack 2017), "sets the stage for the continuing subordination of other worlds" (Blaser 2009b, 18) and does not leave space for other worlds or ontologies to co-exist in a way that is legible and perceived as legitimate within the policy environment.

This dominant fisheries ontology that centres 'the fisher' as a full-time, profit-maximising, rational economic subject, targeting a quota-controlled single species 'fish/resource' at designated times of the year has been challenged for not creating space for fishing activities that could enact a different kind of economy to that shaped by large-scale operators and bring into being multiple possible fisheries worlds (Nightingale 2011; Snyder and St Martin Snyder and St Martin 2015; Bresnihan 2016; Bresnihan 2019). The Irish Islands Marine Resource Organisation (IIMRO) ${ }^{9}$ is a grassroots, island communities-based organisation and cooperative that was set up in 2014 as an affiliate of Comhdháil Oileán na hÉireann (the Irish Islands Federation) in 2014 to represent the voices of Ireland's island communities on marine-related matters. The eighteen islands are home to a dwindling population of approximately 3000 people, with ninety-eight registered small-scale vessels, of which sixtyfive have multi-purpose licences which entitle them to fish

\footnotetext{
$\overline{7}$ Harnessing Our Ocean Wealth - An Integrated Marine Plan (IMP) for Ireland https://www.ouroceanwealth.ie/sites/default/files/sites/ default/files/Harnessing\%20Our\%20Ocean\%20Wealth\%20Report.pdf 8 https://www.gov.ie/en/publication/60e57-national-marine-planningframework/

${ }^{9}$ www.iimro.org
} 
for certain quota-controlled species. Forty-three of these island vessels are members of IIMRO. Commercial fishing on the islands is a seasonal, part-time activity, usually carried out in "smaller boats [that] fish a lot of different species, they're not specialised" ${ }^{\prime \prime}$. Since 2014, IIMRO has endeavoured to bring into being its vision for communities-based, seasonal, mixed fisheries across the islands, co-managed in collaboration with relevant government agencies and departments. These endeavours have generated struggles as the island fisheries ontologies try to enact "a more heterogeneous network of relations" (Brattland 2014, 4) in a policy environment that privileges State fisheries ontologies historically designed around large-scale operators and market logics (as illustrated below). Two policy initiatives, driven by IIMRO and aligned with island fisheries ontologies, proved to be of particular ontological interest. In the next section, I use the concept of political ontology (Blaser 2009b) to probe how these initiatives bring islands and State fisheries ontologies into conflict with each other. This leads to the identification of five ontological assumptions underlying State fisheries policy that operate to subordinate ontologies of island fisheries.

\section{Arriving at the ontological assumptions that underpin fisheries governance approaches in Ireland}

Access to quota-controlled stocks emerged as a significant point of contention throughout the interview process and provided what Flyvbjerg et al. $(2012,2016)$ call a tension point - a site of dynamic power relations that is characterised by contested knowledge and conflict. The tension point around quota-controlled stocks suggested the existence of "different stories [that] imply different ontologies or worlds" (Blaser 2014, 54). Following Blaser (Blaser 2009b, 11), my point of analytical departure was that the tension point was created "not because there are different perspectives on the world but rather because the interlocutors are unaware that different worlds are being enacted (and assumed) by each of them". Using the concept of political ontology (Blaser $2009 \mathrm{~b}$ ) to probe the politicised nature of the practices and processes that bring different fisheries worlds into being, and with attention to the tension point around access to the supposed public resource of quota-controlled stocks, I identified five ontological assumptions that "manifest themselves as 'stories"' Blaser 2013a, 22) within Irish State fisheries governance approaches. The process of identifying these ontological assumptions involved a tracing backwards from the fisheries world enacted by policy instruments, institutions and fisheries management approaches that determine access

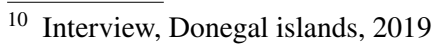

to quota-controlled species. A key question that guided this tracing process was which fishers, fish and fishing activities are being produced (or not) as legitimate and legible for the State's fisheries management purposes? Boucquey $(2020,179)$ points to the "key ontological role" played by those who have control over drafting plans and policies in terms of setting the parameters for discussion going forward. Bresnihan $(2019,170)$ observes that Irish fisheries management is committed to "working on what it assumes to exist (rational economic subjects, commodity markets, uncertain marine environments), rather than challenging these basic coordinates". With this in mind, I attended carefully to the struggles by islanders to make island fisheries ontologies legible and legitimate within the policy environment as they interacted with historically-embedded political narratives that shaped a fisheries ontology around large-scale operators landing quota-controlled species into four major ports.

Two recent policy initiatives have attempted to disrupt the dominant approaches to fisheries management. The Island Fisheries (Heritage Licence) Bill, proposed in 2017, can be understood as an attempt to assert and make legible within fisheries policy a world of socio-ecological rhythms familiar to island fishing communities. It proposes that a small percentage of Ireland's annual national quota allocation would, in relation to island-relevant species, be ring-fenced as community quota for licensed island fishers who would be identified in a new, differentiated sub-segment of one of the existing fleet segments. This would allow smaller island boats to fish this ringfenced quota more flexibly, for example by fishing valuable pelagic stocks (within the ringfenced allocation) at the times those stocks appear in island waters, even if this does not coincide with the industry-determined limits of the specialised, offshore pelagic fishery. This legislation has the potential to disrupt the dominant status quo of an ontological reality historically built around a large, profitable, specialised fleet with the capacity to cover vast distances to exploit their fishing opportunities, by creating space for the enactment of a reimagined fisheries world (St. Martin et al. 2015; Snyder and St Martin 2015) designed around small-scale part-time operators operating a seasonal mixed fishery where boats switch flexibly between a range of different fishing gears depending on the species that appear in island waters. The progress of this legislation through the Dáil (Irish Parliament) was blocked in 2019 by the Minister for Agriculture, Food and the Marine on the ground of incompatibility with the Common Fisheries Policy and related regulations. This alleged incompatibility has been contested (see Brennan 2019). Although it is still in the legislative system, the Bill has not yet been considered by the existing administration which took office after the February 2020 general election.

The second initiative involved IIMRO's application for recognition (by the Department of Agriculture, Food and 
the Marine) as a fish producer organisation, a process that IIMRO initiated in 2019. IIMRO finally achieved producer organisation status in February 2021 (DAFM 2021). Producer organisations are officially recognised bodies set up by fish producers for the day-to-day management of fisheries. The four producer organisations that already existed represent predominantly large-scale vessels and account for a combined membership of approximately $10 \%$ of the Irish fishing fleet. IIMRO's application for recognition as a new producer organisation revealed a policy process that operated to subordinate island fisheries ontologies to a fisheries world shaped by large-scale operators (Blaser 2009b). IIMRO's initial application (in 2019) could not fulfil a criterion that required at least $30 \%$ of the producer organisation members' catch to be landed into one of Ireland's four main fishing ports. Most island boats do not land into these big ports. They fish close to home and land into their nearest port, due to time, weather and financial constraints. Even when the application criteria were updated to facilitate smaller vessels (and to align with the most recent EU regulations on producer organisations), island ontologies still struggled to be enacted. Under the revised criteria, the organisation applying for producer organisation status must have a minimum of thirty members who are documented as active, commercial fishers. However, nineteen of IIMRO's forty three boat-owning members were deemed ineligible due to lack of documentation to prove they were actively fishing, even though many of these were vessels under 10 $\mathrm{m}$ which are not legally obliged to keep logbooks. In order to legitimise these nineteen island vessels within the State's fisheries ontology, IIMRO sought out alternative documentary evidence to prove that these boats were actively fishing, including evidence of participation by these vessels in a fisheries research project with the State research agency and evidence of their receipt of funding for safety equipment from Bord Iascaigh Mhara (Ireland's Seafood Development Agency).

The recognition of IIMRO as a new producer organisation, representing small-scale island fishers, has made the world of island fisheries noticeably more legible within the State's fisheries ontology. IIMRO is now represented on important decision-making committees to which producer organisations have access, such as the Quota Management Advisory Committee, which manages whitefish stocks and certain mackerel stocks (those targeted by under $18 \mathrm{~m}$ vessels using ring nets). Up to 2016, members of this committee included representatives from the Department of Agriculture, Food and the Marine, the four existing fish producer

\footnotetext{
11 These members sit on separate management committees for pelagic stocks such as herring and mackerel, which are managed on an annual or seasonal basis, with catch limits largely determined according to historical catch records. The two fishing associations are
}

organisations, and two other fishing associations. ${ }^{11}$ In 2016, the National Inshore Fisheries Forum (set up by the State in 2014 to represent the $86 \%$ of the Irish fleet that comprises inshore fishers) was appointed to the committee. Since its recognition as a producer organisation, IIMRO has also been appointed to a taskforce, set up in 2021 by the Minister for Agriculture, Food and the Marine, to provide recommendations for local coastal communities in the wake of Brexit.

It remains to be seen to what extent this new representation and legibility within the policy environment will enable island fisheries ontologies to assert and sustain their worlds within an ontology that has so often subordinated them. The mostly part-time, seasonal, small-scale island fisher, fishing mainly non-quota species, bears little resemblance to the highly mobile, full-time, economically productive, profitmaximising fisher constructed by fisheries policy, market forces and increasingly specialised fishing practices. Even though the vast majority of vessels in the Irish fleet (approximately 1200 out of a total of approximately 1400 vessels) are small vessels under $12 \mathrm{~m}$, they generate only $20 \%$ of the economic value of the Irish fishing fleet's total landings in the inshore (0-6 nautical miles) zone, and an even smaller share (1\%) when all fishing areas are taken into account (BIM 2017). Although there is explicit policy recognition of "the socio-economic importance of the fishing industry in the coastal communities dependent on fishing" (DAFM 2016, 1; DAFM 2019, 2), it speaks to the incommensurability of different fisheries ontologies (in this case, State and island fisheries ontologies) that, over the last two decades, small-scale fishers (including island fishers) have become increasingly reliant on fishing non-quota species in a much less diverse fishery. One islander remembered a conversation with a friend who worked as a scientist for many years in Bord Iascaigh Mhara, Ireland's Seafood Development Agency:

I remember him saying to me at one time that they could only think in terms of the big operators. They did not seem to be able to get their head around how the small operators, seasonal people worked. They couldn't, almost in a sense they couldn't see any point in developing a fishing policy for people who only operated seasonally. Like they were so insignificant that they almost weren't worth considering. ${ }^{12}$

A focus on those operators producing the vast majority of the economic value of landed catch together with preferential access for highly productive operators is indicative of a management approach driven by market logics. It reflects the politicised construction of "commodity fisheries as a

\footnotetext{
Footnote 11 (continued)

the Fishing Co-operative Association and the Irish Fish Producers and Exporters Association.

12 Interview, Mayo islands, 2019
} 
natural domain, of which fishers are atomistic extractors to be managed" and "the bioeconomic creation of fish stock and broader political economies" (McCormack and Forde 2020,1). The influence of market logics is evident from the State's concern at quota being wasted if the full allowance was not landed and the assumption that market price is the main factor determining where fishers choose to fish. According to the 1990 annual report from Bord Iascaigh Mhara (the Irish Seafood Development Agency), "the most urgent need is that modern all weather whitefish vessels are brought into the fleet which would catch our underutilised whitefish quota off the west coast and also fish non-quota species in the deeper waters of the Atlantic" (BIM 1990, cited in Fahy 2013). This construction of market-driven commodity fisheries is reinforced by the fishing practices of the larger operators.

The ontology of quota-controlled stocks as State-owned common property (see DAFM 2016; DAFM 2019) conflicts with technocratic requirements that complicate such access for smaller vessels and, in particular, for island vessels. Historically, quota-controlled fish are established in the State narrative as a public resource that are accessible to licenceholders. However, for many licensed island fishers, these same fish stocks bear more of a resemblance to private property since, in practice, access to this common property is largely restricted (for example, through technocratic requirements) to the economically productive, highly mobile, fulltime fisher operating in a directed (single species) fishery. For example, capacity rights (which are required as part of the licensing process) are privately owned assets. This is partly due to Common Fisheries Policy rules that cap the permitted amount of tonnage and engine power in member states (Carpenter and Kleinjans 2017). The Department of Agriculture, Food and the Marine guidance notes on seafishing boat licensing and registration provide that "[c] apacity in the form of gross tonnage and engine power... is a privately owned tradable asset... on the tonnage market. Capacity must be provided by licence applicants at a ratio of 1:1 as part of the licensing process..." (DAFM 2020, 5). All fishing vessels must therefore buy privately traded general tonnage as part of the licensing process in order to access publicly owned fishing opportunities. As Carpenter and Kleinjans $(2017,172)$ note, this requirement "appears to be at odds with Ireland's commitments towards managing fish stocks as a public resource as part of the access rights are private". The filtering of individual fish stocks through the technologies of kilowatts, tonnage and track record has reshaped the public nature of the resource and produced fish that increasingly resemble privatised assets. This was captured by one island small-scale fisher's frustration that "if you're not in some of those fisheries you can't get into them. You need track record and tonnage and kilowatts". 13

Another island fisher pointed out that "people are banking it up and not using it, the kilowatts and tonnage, and this is ridiculous." 14 At the European level, a combination of fisheries science and annual political negotiation amongst member state's fisheries ministers have produced biophysical fishing grounds with an ecology of single species stocks - through the annual allocation of quota shares, the setting of total allowable catch (TAC) for individual stocks and the individual stock assessments carried out by the International Council for the Exploration of the Seas (ICES), that underpin recommended TACs (see Holm and Nielsen 2004; Schwach et al. 2007). Price and other market-driven logics are assumed to determine fishing decisions to catch and land these stocks.

This analysis points to five ontological assumptions that underpin Irish State fisheries governance approaches. These assumptions 'bump heads' with IIMRO's attempts to assert island small-scale fisheries as a differentiated world within this governance system. I have categorised these ontological assumptions as social-historical, ecological, geographical, technocratic and markets-driven:

(i) Social-historical: The resource is a public asset; any fisher who has a polyvalent (multi-purpose) licence can access fishing opportunities for quota-controlled species and any move towards privatisation of the resource would be detrimental to fisheries-dependent coastal communities and should be resisted.

(ii) Ecological: Fisheries are managed as single species stocks underpinned by individual stock assessments.

(iii) Geographical: Fishing vessels are not tied to a specific geographic location.

(iv) Technocratic: Smaller vessels can be managed within the paradigms of the current governance system.

(v) Markets-driven: The economic value of the resource should be maximised to avoid waste such as unused quota. The most (economically) valuable and productive operators are entitled to preferential access to certain stocks.

I have framed these assumptions as ontological (what we know), even though I recognise that they contain elements of epistemology (how we know what we know) and axiology (how we think about, and manage, values and preferences). As such, I agree with Williams $(2014,2018)$ that ontological, epistemological and axiological pluralism are fundamentally interrelated. For example, the Technocratic

\footnotetext{
13 Interview, Donegal islands, 2019

14 Interview, Cork islands, 2019
} 
and Markets-driven assumptions are embedded in a utilitarian worldview that understands preferences and values as external to the policy process, interest-based and subject to trade-offs. The Social-historical, Ecological and Geographical assumptions reflect an epistemology that does not acknowledge its positionality and that is defined by those in positions of power (for example those who have access to decision-making tables where they can leverage their interest-based preferences). Notwithstanding this, I believe that the relevance of ontological considerations to fisheries governance justifies proceeding on the basis of an ontological framing.

The next section presents a more detailed analysis of Irish fisheries policies in light of these ontological assumptions. I argue that these ontological assumptions are being challenged by Irish islanders' attempts to make visible the 'islandness' of island small-scale fisheries within Irish fisheries governance institutions and discourses as a distinct category. This 'islandness' is articulated in islanders' assertion of fish, fishers and fishing activities in ways that compete with the fish, fishers and fishing activities imagined and produced by the policies, practices and politics of the fisheries governance system. I show how these ontological assumptions have stymied efforts to reimagine island fisheries governance, as competing ontologies have been cast, by the State, as a dangerous step towards the privatisation of fishing opportunities by unfairly privileging a small group of island fishers.

\section{The operation of ontological assumptions in Irish fisheries policy}

\section{Social-historical: the resource is a public asset, and any fisher who has a polyvalent licence can access fishing opportunities for quota-controlled species}

The State's ontological assumption that the fisheries resource is (and should be) a public asset is clearly articulated by the Department of Agriculture Food and the Marine (DAFM):

In Ireland, quota is a public resource and is managed to ensure that property rights are not granted to individual operators. This is seen as a critical policy in order to ensure that quotas are not concentrated into the hands of large fishing companies whose owners have the financial resources to buy up such rights. In Ireland, any movement towards privatisation and concentration of rights into the hands of large companies would seriously risk fishing vessels losing an economic link with Ireland's coastal communities and undermining the socio-economic importance of the fishing industry in the coastal communities dependent on fishing. The result of this long standing policy is that the Irish fish- ing fleet involves a balanced spread of sizes and types of fishing vessels who have retained a strong economic link with our coastal communities and have delivered economic activity including vital employment in these communities, where there are very limited alternative economic activities (DAFM 2016, 1; DAFM 2019, 2).

In Ireland, unlike in other EU Member States, quota is State property and is not transferrable between vessels (although the Quota Management Advisory Committee can engage in quota swaps with other member states). The Quota Management Advisory Committee (also known as the whitefish committee) determine how much of each quotacontrolled whitefish stock in Irish waters can be fished by the various fleet segments each month. According to this story of a public resource that is accessible to all polyvalent licence-holders, no fisher or group of fishers is deserving of differentiated treatment because "everyone in Ireland is equal, they are Irish, so they have access to Irish waters" ${ }^{15}$.

In practice, however, differentiated treatment exists within the fisheries management system for certain categories of fishing vessel and fish species. Ireland's specialised mackerel and herring fleets are entitled to specific quota allocations for individual vessels while other (non-pelagic) vessels fish against two different common quota pots, depending on whether a vessel is over or under $18 \mathrm{~m}$ (with the over-18-m vessels getting double the quota allocation of the under- $18-\mathrm{m}$ vessels):

The Quota Management Advisory Committee...set [quota] ratios that are maintained, these are historical ratios and there are different ratios for different species. ${ }^{16}$

As such, the quota management system involves categorisations and quota allocation ratios that continue to enact (or bring into being) particular fisheries 'realities' that are "historically, culturally and materially located" (Mol 1999, 75) and, thereby, to stifle other, possible realities that 'bump heads' with the status quo. It is difficult to transform the status quo when it is reinforced by the locking in of elements in the system by path-dependent decision-making (Kelly et al. 2019). A good example is the persistence of the historical categorisations of fleet segments into under$18-\mathrm{m}$ vessels and over-18-m vessels. The material realities of smaller (under $12 \mathrm{~m}$ ) vessels are subsumed within a categorisation that is designed around larger vessels, although attempts have been made to acknowledge these material realities. Since 2014, the State-created National Inshore

\footnotetext{
${ }^{15}$ Interview with representative of Department of Agriculture, Food and the Marine, 2019

${ }^{16}$ Interview with representative of Department of Agriculture, Food and the Marine, 2019
} 
Fisheries Forum (representing under 12-m vessels) has occupied a seat on the Quota Management Advisory Committee (QMAC), who meet monthly to decide on catch limits for quota-controlled whitefish stocks. In deciding on monthly quota allocations,

the QMAC operate by examining in detail each month the operation of each fishery, available quota and uptake patterns for the different metiers of fishing vessels, including inshore fishing vessels. There are detailed discussions each month on allocations taking account of the divergent situation of the fleet, including that of smaller inshore fishing vessels, and of the market. The Committee may also take account of the weather/sea conditions in the preceding quota period and the impact this may have had on the industry during that period, particularly in respect of the smaller vessels. (DAFM 2016, 1).

The problem is that current fisheries management categorisations have been devised on the basis of a particular story or historical assumptions around access to Irish fisheries resources. Ontological assumptions that long predate the more recent policy recognition of smaller-scale vessels thus underpin which fishing entities exist within DAFM's fleet segment categories and the practices by which they become known (e.g. whether they are entitled to an individual quota allocation or depend on a lottery or a carve-out to access quota-controlled species). (A carve out involves a small percentage of a quota-controlled species being set aside for vessels of a particular size and/or using a particular type of gear, who do not fulfil requirements to access fishing opportunities for such species.) As such, particular 'worlds' or ontological 'realities' are reinforced by the categorisations and the practices they require (Sullivan 2017). The dominant ontological reality that has been historically structured around larger, specialised, industrial vessels has not been disrupted by the ontological realities inhabited by small-scale (under $12 \mathrm{~m}$ ) vessels. Rather, the State has, quite literally, carved out sections of this historical status quo for these smaller vessels in the form of small percentages of quota allocations that are set aside for smaller vessels. An exception to this practice is a policy directive that prohibits over-18-m vessels from fishing within 6 miles from shore, which is the area relied on by inshore fishers for all of their income (BIM 2017). The ban, which took effect in January 2020, was temporarily overturned (on the basis of a procedural issue) in a court case taken by the owners of three over-18-m vessels but subsequently reinstated on appeal to a higher court. Despite the concessions mentioned above, the historical fisheries management categories continue to reinforce a 'world' that privileges larger, specialised vessels, as different requirements combine to frustrate the attempts of small-scale vessels to assert a reality that is designed around their differences. The dominant ontological reality is not disrupted. Burman $(2017,935)$ conceptualises as "ontological disobedience" a process of "carving out spaces for the generation of other realities...". IIMRO's efforts can be understood as deliberately disruptive and an example of ontological disobedience, as these efforts seek to assert the material realities of island small scale fishing communities within the dominant 'one-world world' (Law 2011, cited in Blaser 2013b) of Irish fisheries policy and management. The next section reinforces how the social-historical assumption of access to fishing opportunities as a public resource is challenged by the socio-ecological rhythms of island smallscale vessels fishing inshore waters around the islands.

\section{Ecological: fisheries are managed as single species stocks}

As explained previously, single species stock management is the basis of fishing management approaches in the EU, including Ireland. Fisheries scientists, policymakers and implementers are, of course, aware of multi-species interactions (e.g. predator-prey) and interactions in a mixed species fishery (such as bycatch or non-target species being mixed in with target species). The latter is of critical concern since the introduction of the EU's landing obligation (a ban on discarding unwanted fish) in January 2019, which could lead to early closure of mixed fisheries when the catch limit for one of the stocks has been reached (DAFM 2019).

The ontological insight here is that the single species stock management approach asserts a reality that is aligned with larger vessels using specialised fishing gear and covering large distances to follow and target large volumes of a high value, single species (such as mackerel or herring) within season limits set by the fisheries authorities.

A different ecological reality materialises in the fishing grounds accessible to small-scale vessels, whose waters are characterised by mixed stocks that appear and disappear at different times of the year, according to a variety of factors, such as migration patterns. Small-scale vessels inhabit a reality where they must wait for different stocks to appear within their much more limited reach (discussed further in the "Geographical ontological assumption" section below). The seasonal appearances of quota-controlled stocks in inshore waters around the islands may not correspond to the official season for certain species (when fishers are permitted to start fishing for certain quota-controlled species), thus failing to ontologically capture the socio-ecological rhythms of the inshore waters experienced by island fishers:

I think the herrings, you can only fish them later in the year. Say if they were here early, that we would be allowed to catch them when they are in our area rather than having to wait until the season is open.... [so] when the fish arrive on our shores that we could 
automatically catch them while they are there...they will disappear again. ${ }^{17}$

The reinforcement of the dominant ontological reality of larger industrial vessels is visible in how the seasons for pelagic species are determined:

The fishing of pelagic species is generally confined to the spring and autumn months with the fisheries being opened and closed by the Minister on the basis of industry recommendations and catch levels (DAFM 2016, 2, emphasis added).

The pelagic fleet (numbering 50 vessels) is a highly specialised, industrialised and economically profitable fleet, in particular the 23 vessels belonging to the ring-fenced Pelagic Refrigerated Sea Water fleet segment, who benefit from individual vessel allocations of the vast majority of quota for pelagic species. Pelagic vessels tend to fish far offshore. As the season limits recommended by the pelagic industry are unlikely to focus on the timing of appearances of valuable pelagic stocks such as mackerel and herring in inshore waters (which may not even be predictable from year to year), the dominant ontological reality of larger industrial vessels is not disrupted by the carve outs from pelagic quota allocations for smaller vessels.

The attempts of the Island Fisheries (Heritage Licence) Bill to reconfigure island fisheries as a differentiated subsegment within the State's fleet segment categories has generated significant friction with those ontologically aligned with the State's approach to fisheries governance, who view the legislation as a move towards privatisation of Irish quota. Accordingly, the legislation must be resisted, as per the social-historical ontological assumption outlined in the "Social-historical: the resource is a public asset, and any fisher who has a polyvalent licence can access fishing opportunities for quota-controlled species" section above. I consider below (in the "Technocratic: Smaller vessels can be managed within the paradigms of the current governance system" section) the contradictions within this reading of the proposed legislation and how this resistance is undermining the State's commitment to protecting fisheries-dependent communities.

\section{Geographical: fishing vessels are not tied to a specific geographic location}

The privileging of the 'world' of specialised fleets, underpinned by single species stock management, feeds into the ontological assumption that fishing vessels are not tied to a specific geographical location, and that fisheries policy

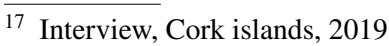

should not provide fishing opportunities based on differentiated geographical constraints across the fleet. Despite the State's awareness of the "divergent situation of the fleet, including that of smaller inshore fishing vessels", a reinforcement of the ontological reality of the larger, more specialised vessels is clear from an explanation given by a DAFM representative as to why a ringfenced quota for island small-scale vessels would set a dangerous precedent:

Boats don't obey a geographical location. They land fish and catch fish based on where the fish are and where they get the highest price. The sea is joined up wherever you are, it is only the land that separates it. There would be huge hostages to fortune if the Department [of Agriculture, Food and the Marine] established the principle that gives different opportunities based on where you are geographically. Fish move, boats move and you can land into different ports ${ }^{18}$.

The assumption that fishing vessels are not tied to a specific geographical location also underpins the allocation of fishing opportunities. In practice, smaller vessels have more limitations than larger vessels, and access fishing opportunities differently. For safety reasons, smaller vessels cannot fish in the same conditions or as far offshore as larger vessels. Smaller vessels have a much shorter range and do not travel far from their home port. Bad weather conditions limit their days at sea, choice of fishing grounds and result in shorter fishing seasons. Larger vessels tend to be more specialised in gear in the species targeted and can travel far from their home ports. As mentioned above, the State is clearly aware of the "divergent situation of the fleet" to the extent that such differences are stated to be considered in quota allocation decisions. The point here is twofold: (i) the ontological assumptions underlying the fisheries governance system privileges those vessels that are not tied to a geographical location, that can follow fish rather than wait for them to appear and that can choose which port to land into and (ii) recognition of the "divergent situation of the fleet" while remaining embedded in a system that was historically constructed around the ontological reality of an extremely profitable and comparatively small part of the fleet (approximately 14\% of the Irish fleet fish in offshore waters) reinforces the notion of a 'one-world world' (Law 2011, cited in Blaser 2013b) where other 'worlds', such as that of island fishing communities, are relegated to a carved out niche within a 'world' to which they do not belong.

Although it does not explicitly mention preferential access for small-scale fisheries, Article 17 of the Common Fisheries Policy attempted to account for such differences

\footnotetext{
18 Interview with representative of Department of Agriculture, Food and the Marine, 2019
} 
within member state fleets by requiring member states, when allocating fishing opportunities to their national fishing vessels, to "use transparent and objective criteria including those of an environmental, social and economic nature.... Member States shall endeavour to provide incentives to fishing vessels deploying selective fishing gear or using fishing techniques with reduced environmental impact, such as reduced energy consumption or habitat damage". In practice, the European Commission is powerless to challenge member states on whether measures they have implemented pursuant to Article 17 (such as carving out certain quota allocations for artisanal and small-scale fishers) are effective in providing equitable access to quota controlled species for smaller vessels, as member states have discretion on how to implement this provision. While DAFM has implemented certain measures pursuant to Article 17, such as carve outs for smaller vessels without track record to access certain quotacontrolled species, such access does not always materialise in practice when the access is determined by the technocratic rules of a 'world' that has been designed for vessels inhabiting a different material reality.

\section{Technocratic: smaller vessels can be managed within the paradigms of the current governance system}

As argued earlier, the recognition by the State of fleet diversity is embedded in a system that is designed around an assumption of commensurability between small and large vessels in terms of ability to access fish stocks. This assumption can also be found amongst the four main fish producer organisations, whose members tend to be larger vessels. Commenting in a webinar on "Producer organisations and cross-border cooperation in small-scale coastal fisheries: challenges \& opportunities", the CEO of one Irish producer organisation commented that "a Polyvalent $5 m$ vessel share of the monthly quota is the same as a $17 \mathrm{~m}$ vessel showing the smaller vessel has more fish to catch than the larger vessel up to $17 \mathrm{~m}$ boat" ${ }^{19}$. A similar line of argument was put forward by the (then) Minister for Agriculture, Food and the Marine in a 2019 parliamentary debate on the draft legislation proposing ring-fenced community quota for island fishers. The Minister argued that the legislation was unnecessary because an imminent exclusion of larger (over $18 \mathrm{~m}$ ) trawlers from the 6-mile coastal zone represented a likely reduction of $2.6 \%$ ( $€ 5.5$ million) of their overall landings, which translated to a potential increase of $62 \%$ in the value of their landings for smaller vessels, who would have the

\footnotetext{
$\overline{19}$ Patrick Murphy CEO Irish South \& West Fish Producers Organisation. Producer organisations and cross-border cooperation in small-scale coastal fisheries: challenges \& opportunities Webinar, 10 June 2020. Organised by DG MARE and Tetra Tech International Development
}

opportunity to fish herring and sprat in bays and coastal areas no longer accessible to large trawlers. This equation of $-2.6 \%$ for $>18-m$ vessels $=($ potentially $)+62 \%$ for $<18-m$ vessels ignores the fact that the polyvalent (multi-purpose) fleet segment has two sub-segments that separate over-18-m and under-18- $\mathrm{m}$ vessels. It is not permitted to transfer capacity (quota) between these sub-segments. The smaller boats cannot apply to access herring quota that would have been used by the larger trawlers to fish herring in these bays and coastal areas, as this quota has been allocated to a sub-segment to which the smaller vessels do not belong (Brennan 2019). Although there is a carve out for north west herring of up to $5 \%$ of the quota, this is for "vessels under $20 \mathrm{~m}$ without a track record on the basis of modest monthly catch limits" (DAFM 2016, 4) and not specifically for small-scale vessels. The north-west herring carve out that is specific to small-scale vessels is restricted to "punts" (small, open deck vessels) that use a specific type of fishing gear - "Artisanal draft ring-net fishing" (DAFM 2016, 4). This means that small-scale vessels without track record for herring that are not punts (such as half-deckers) ${ }^{20}$, and that use gill nets rather than ring nets to commercially fish for herring, are not able to access this carve-out. They must compete with larger, more mobile vessels (up to $20 \mathrm{~m}$ ) for "modest monthly catch limits" that are not specific to small boats.

A central focus of fisheries management in this system is ensuring that quota allocations are efficiently used as a profit-maximising resource. As discussed earlier, there is concern that allocation of valuable fishing opportunities to the small-scale fleet might be wasteful and result in quota allocations not being fully used. This is indicative of the markets-driven logic dominating the system.

\section{Markets-driven: the economic value of the resource should be maximised to avoid waste such as unused quota. The most (economically) valuable and productive operators are entitled to preferential access to certain stocks}

Despite the State's ideological commitment to safeguarding fisheries as a public resource, the national quota management system has historically developed to favour the largest, most efficient and most productive operators.

Fishing is rooted in those who are willing to take risks back in the eighties and nineties and everything was set in stone after that. That is why they get preferential access to it now, nothing has changed that view since 21

\footnotetext{
${ }^{20}$ A half-decker has a small enclosed cabin, which means the deck is not completely open. A punt does not usually have an enclosed cabin.

${ }^{21}$ Interview with representative of Department of Agriculture, Food and the Marine 2019
} 
The State's focus on "improving the economic performance of the fleet" under its Fisheries Operational Programme (DAFM 2018a, b, 10) underlines how the State continues to equate the value of fishing with economic output. Amongst the small scale island fleet, some fishers appeared to accept this approach as inevitable:

But that is realistic because these people are making money and that is what the government sees, and that works. Capitalism. ${ }^{22}$

The State's response to increased fishing pressure on mackerel stocks at the turn of the twenty-first century was clearly driven by market logic. It ringfenced virtually all of the mackerel quota to the larger vessels, effectively creating a specialised mackerel fleet. Thus, in 2010, the $80 \%$ of Ireland's annual mackerel quota that had been ringfenced to twenty three pelagic vessels a few years previously was joined by a new ringfenced category: twenty seven of the larger polyvalent boats were allocated the remaining $20 \%$ based on their track record of catching mackerel. The only open access mackerel quota that remained was the 400 tonnes carved out or set aside for the small-scale, artisanal fleet who possessed boats with polyvalent licences.

It is clear that the State believes that this rational, marketdriven approach is based on fairness:

The Irish fish quota management system is designed to ensure, having regard to fishing patterns and market conditions, a fair and rational allocation of quotas between fishing vessel operators and management to support fishing seasons and the availability of by-catch quotas during the year (Oireachtas 2020).

Once again, the issue here is not the existence of a markets-driven ontological assumption in and of itself. Rather, it is the resulting erasure or subordination (Blaser 2009b) of different worlds or ontologies that could also be legible within the policy domain. Even though they had lobbied for it, the imposition of the ban on larger vessels fishing within the 6-mile limit was a surprise for the inshore sector, not least because this spatial initiative recognises, at a policy level, the need for a differentiated approach for the small-scale fleet as well as providing inshore fishers with preferential access to stocks in inshore waters.

The Norwegian "mixed economy" approach to fisheries governance shows that, despite a shift towards neoliberal, market-based approaches in that country, it is possible to create policy outcomes that address the inequities, inequalities and power imbalances that would arise from an over-reliance on the market to regulate itself. In Norway, the state, cooperative institutions and market instruments

$\overline{22}$ Interview, Mayo islands, 2019 work together on negotiated outcomes by blending hierarchical, co-management and market-driven approaches and pragmatism and a focus on finding solutions is valued over any particular ideology (Johnsen 2020). As Johnsen (2020, 457) observes,

In the Norwegian governance system, negotiations and partnership arrangements form a bridge between hierarchical state control and market forces. The legal framework in Norway mandates co-management solutions. However, the laws do not specify in detail the regulatory instruments to be used, thus giving freedom to find practical solutions. Negotiated solutions between stakeholders and authorities that are politically guaranteed through compromises in the Parliament are thus common in Norwegian fisheries' policy. Some of the compromises, such as the system for allocating quotas to vessel groups, have survived for more than 25 years.

\section{The interplay between the ontological assumptions}

A close examination of Irish island fishing practices around access to quota-controlled stocks within the prevailing fisheries policy context reveals how the interplay between these ontological assumptions "perform themselves into worlds" (Blaser 2009a, 877), and how their enactment subordinates efforts to assert island small-scale fisheries ontologies (fishers, fish and fishing practices) as a differentiated 'world' within this governance system. Despite the State's ideological commitment to maintaining Irish fisheries as a public resource that supports fisheries dependent coastal and island communities, the last two decades have seen the small scale fleet become increasingly specialised while access to quota controlled species is concentrated in the hands of the larger, industrial vessels. In practice, access is contingent on being aligned with the logics of the State ontology, such as being an economically productive fisher in the right fleet segment and satisfying the requisite technical parameters (track record, tonnage and/or kilowatts). This reproduces existing asymmetries of power within fisheries governance, privileging the larger, industrial fleet, whose material realities dominate current fisheries governance approaches.

To navigate the governance system and gain access to quota species, an island fisher must negotiate "both material limits, such as the reproductive cycle..., and opportunities, such as the momentary presence of fish...reveal[ing] something that is not captured by simple biological or economic indicators - a relationship to the shifting possibilities that inhere in any particular context" (Bresnihan 2016, 144-145). These shifting possibilities need to combine in particular ways for the island fisher to be able to access fish: 
Because these limits (and opportunities) change, often from moment to moment, the ways they are identified, negotiated and responded to must be dynamic, flexible and open to contestation (Bresnihan 2016, 146).

The ontological assumptions underpinning State fisheries policy can combine in various ways to frustrate the dynamism and flexibility needed to access fish: when quotacontrolled species appear in inshore waters (ecological), is it the permitted season to fish them (technocratic), is the vessel in the correct fleet segment with the requisite tonnage, kilowatts and track record (technocratic), do the tides and weather allow the fisher to access the fishing grounds and go to sea safely, does the available daylight shorten the fishing day as the fisher coordinates landing their catch at a mainland pier, returning to the island to moor the boat offshore (if there is no pier infrastructure) and safely bringing the boarding boat back to shore before darkness falls (geographical)? For islands situated further away from the mainland, will the fisher target shellfish, which can be stored at sea, or any quota-controlled species that have appeared in inshore waters (ecological), bearing in mind that the latter need to be landed the same evening (as island boats are too small to have ice on board) and transported to the mainland the next time a cargo boat leaves the island (marketsdriven)? The prevailing social-historical policy assumption that these fisheries are accessible as a public resource serves to mask the way that these ontological assumptions assemble themselves in a myriad of different ways which can block access for small-scale fishers.

These impediments to island fishing activities operate to subordinate island fishing ontologies (fish, fishers and fishing activities) and prevent the reimagination of local fisheries economies (Snyder and St Martin 2015; Mather et al. 2017) as it is difficult for island fishers to flexibly fish for different species when stocks appear in island fishing grounds. Yet, words tend to fall short when it comes to portraying the realities of the ontological squeeze on island fishers. Brennan and Rozanov (2020) have attempted to address this challenge in an animated representation of the complexity of the issues at play.

Another illustration of the interplay between ontological assumptions (ecological, geographical and markets-driven) is evident from the failure of an island initiative to develop a niche brand for "island fish". On several occasions during the fieldwork for this research, I heard from small island businesses that a significant issue with developing and marketing "island fish" was a difficulty in accessing locally caught fish from island fishers. One island business owner invested in setting up a processing kitchen with the aim of sourcing whitefish from local fishers, an initiative that was frustrated by lack of volume and inconsistent supply of island fish. On this island, there is only one boat left that catches whitefish. However, the main focus of this boat is targeting shellfish. Fishers might cast their nets for whitefish on returning from a day shooting or hauling shellfish pots but whitefish is not their main target.

If there was five fishermen out there working the exact same as John ${ }^{23}$ I think it would make life a lot simpler for us without a doubt.... Sometimes the five on a Thursday evening phone call of 'I have a load of boxes of pollock' and you just want to tear your hair out, you are really going ' $\mathrm{f} * * \mathrm{k}$ '! Did you have any idea you were going to do that? If I had known that yesterday... ${ }^{24}$

The incidental and non-targeted nature of whitefish catch for many small-scale fishers reflects the increasing lack of diversity in Irish small scale fisheries, and has not gone unnoticed by the State:

Over the past 20 years, fishing vessels under $12 \mathrm{~m}$ in length have become increasingly specialised, targeting fewer species and becoming increasingly reliant on a limited number of fish stocks. The majority of their fishing effort is now directed on shellfish (lobster, crab, shrimp, clams), whereas previously they also fished for salmon, skates and rays, whitefish (cod, haddock, whiting, pollack), flatfish (turbot, plaice, sole) and herring amongst others. There is a domino effect here as the number of stocks available to the sector has declined so that pressure on the remaining stocks increases. Fishing on the main species of shellfish now occurs practically year-round, as opposed to seasonally, because the availability of whitefish and flatfish inshore is now too low to be commercially viable in many cases (DAFM 2018b, 21).

The subordination of island ontologies (fishing practices) is evident here as specialisation; a characteristic of the larger operators and also a familiar characteristic in a privatised fisheries system (McCormack 2017) reshapes small-scale fishing practices into the dominant fisheries ontology. This status quo is difficult to transform within a system that is designed for a different fishing 'reality' and when "instead of attempting to challenge the status quo, fishermen are encouraged to work on what they can influence: the efficiency and profitability of their fishing activity" (Bresnihan 2016, 118). The framing of the inshore fleet as a shellfish fleet (which is what it has become) reinforces the dominant ontological framing that whitefish and pelagic species 'belong' to the larger boats and impedes openings for island fisheries ontologies to be enacted in the policy environment.

\footnotetext{
23 Name has been changed.

${ }^{24}$ Interview, Galway islands, 2019
} 
Notwithstanding these frustrations and difficulties, the proposed Island Fisheries (Heritage licence) Bill and the recent recognition of IIMRO as a producer organisation provide hope.

The legislation has the potential to be an essential element to bringing into being a fisheries governance reality of co-management of a seasonal mixed fishery for the islands by an islands producer organisation working with fishers, technology, island institutions, government agencies, fisheries scientists and social scientists, although it is unlikely to be enacted during the lifetime of the current government. However, the recognition of IIMRO as a producer organisation is significant, not least because this brings island ontologies directly to important decision-making tables. It remains to be seen whether this will be enough of an opening to create possibilities for enactment of island ontologies within the fisheries policy environment, by disrupting the dominant ontological assumptions around fishers (e.g. mobility), fish (how and when they appear in relation to fishers) and fishing activities (as more than simply an economic activity to be managed). It also remains to be seen whether IIMRO succeeds in enacting community-based resource management that manages fishing activities as a more complex practice involving social and emotional integration with both marine spaces and the broader context of fishing communities on land and at sea (Olson 2010; Rossiter et al. 2015; Boucquey et al. 2016; Bresnihan 2016, 2019). Bresnihan (2016, 168) sounds a note of caution here when he observes that:

We are all entangled within institutional and economic practices that shape not only the way we think but also the way we act, the way we work on ourselves and the people, things and places around us.... In this context it is difficult to imagine, let alone enact, a different world, one that is not enmeshed within the rationalities and practices of (neo)liberal capitalism and the scarcity it (re)produces for the majority....

\section{Concluding remarks}

Political ontology has proved to be an effective conceptual tool to illustrate the relevance of ontological considerations to fisheries policy and governance. By attending to the different ontologies or worlds struggling to ensure their continued existence and the politicised nature of practices and processes that bring these different worlds into being (Blaser 2009b), I have identified five ontological assumptions that shape Irish fisheries governance approaches social-historical, ecological, geographic, technocratic and markets-driven and that "are critical to understand given their ability to ultimately affect the material conditions of the fisheries and the socioeconomic lives of fishers"
(Boucquey 2020, 184). I have argued that the squeeze on Ireland's island inshore fishers is not simply spatial; it is ontological. I have demonstrated this ontological subordination (Blaser 2009b) by identifying the assumptions that underpin the State's fisheries approaches, and how these have prevented the creation of spaces that enable island inshore fisheries to be enacted through island logics.

Although the squeezing out of small-scale fishers is experienced by other European small-scale fishing fleets (Brent et al. 2018), the Irish case study presents a particularly complex picture as Irish fisheries are, according to the State, common property and a public resource. I have challenged the dominant narrative of Irish fisheries (in particular, quota-controlled species) as a public resource accessible to all. Despite the Irish State's ideological commitment to maintaining the Irish fisheries resource as a public asset that supports coastal communities, I have argued that it is doomed to fail in delivering this vision in an equitable manner across the Irish fishing industry because its fisheries governance approaches are underpinned by ontological assumptions that establish terms of access to the Irish fisheries resource which, in practice, privilege certain groups of fishers and marginalise others. Moreover, the State is resistant to the disruption of the status quo by competing ontologies that have the potential to more effectively frame and enact the Irish fisheries resource as a sustainably managed public asset across diverse coastal and island communities. I have illustrated how the newest Irish producer organisation, representing small-scale island fishers, is attempting to reshape the ontologies underpinning Irish fisheries governance by making island fishers visible as a differentiated category within the policies and laws that determine how, to what extent and by whom Ireland's quota-controlled stocks are entitled to be fished.

I conclude that, by failing to make space for new ontologies in Irish fisheries governance, the State is continuing to produce a fisheries ontology that is stifling possibilities for the emergence of alternative fisheries ontologies and fisheries governance approaches, while privileging those ontologies (fishers, fish, fishing activities) that do not challenge the status quo. Ultimately, the dominant fisheries ontology that has been created by the interplay of ontological assumptions undermines the State's critical policy to maintain and manage Irish fisheries as a public resource so that opportunities are not concentrated into the hands of large and powerful fishing interests.

Acknowledgements I am grateful to all of the people who participated in this research and who gave generously of their time and knowledge. Thank you to Cormac Walsh and Andrea Nightingale for insightful comments on earlier drafts of this manuscript. I am grateful to two anonymous reviewers and to the editor whose detailed comments greatly improved this paper. 
Funding Open Access funding provided by the IReL Consortium. This project has received funding from the European Union's Horizon 2020 research and innovation programme under the Marie Skłodowska-Curie grant agreement No 789524.

\section{Declaration}

Conflict of interest The author declares no competing interests.

Open Access This article is licensed under a Creative Commons Attribution 4.0 International License, which permits use, sharing, adaptation, distribution and reproduction in any medium or format, as long as you give appropriate credit to the original author(s) and the source, provide a link to the Creative Commons licence, and indicate if changes were made. The images or other third party material in this article are included in the article's Creative Commons licence, unless indicated otherwise in a credit line to the material. If material is not included in the article's Creative Commons licence and your intended use is not permitted by statutory regulation or exceeds the permitted use, you will need to obtain permission directly from the copyright holder. To view a copy of this licence, visit http://creativecommons.org/licenses/by/4.0/.

\section{References}

Bennett, Nathan J. 2019. In political seas: Engaging with political ecology in the ocean and coastal environment. Coastal Management 47. Taylor \& Francis: 67-87. https://doi.org/10.1080/ 08920753.2019.1540905.

BIM. 1990. Bord Iascaigh Mhara Annual Report 1990.

BIM. 2017. Economic analysis of trawl and seine fisheries within the Irish $6 \mathrm{~nm}$ zone. Bord Iascaigh Mhara. Ireland's Seafood Development Agency.

Blaser, Mario. 2009a. Political ontology: Cultural studies without 'cultures'? Cultural studies 23: 873-896.

Blaser, Mario. 2009b. The threat of the Yrmo: The political ontology of a sustainable hunting program. American anthropologist 111: 10-20.

Blaser, Mario. 2013a. Notes towards a political ontology of 'environmental'conflicts. In Contested ecologies: Dialogues in the South on nature and knowledge, 13-27. Cape Town: HSRC Press.

Blaser, Mario. 2013b. Ontological conflicts and the stories of peoples in spite of Europe: Toward a conversation on political ontology. Current Anthropology 54: 547-568. https://doi.org/10.1086/ 672270

Blaser, Mario. 2014. Ontology and indigeneity: On the political ontology of heterogeneous assemblages. Cultural geographies 21: 49-58.

Blaser, Mario, and Marisol de la Cadena. 2018. Pluriverse: Proposals for a world of many worlds. In A world of many worlds, ed. Marisol de la Cadena and Mario Blaser, 1-22. Durham: Duke University Press.

Boucquey, Noëlle. 2020. The 'nature'of fisheries governance: narratives of environment, politics, and power and their implications for changing seascapes. Journal of Political Ecology 27: 169-189.

Boucquey, Noëlle, Luke Fairbanks, Kevin St. Martin, Lisa M. Campbell, and Bonnie McCay. 2016. The ontological politics of marine spatial planning: Assembling the ocean and shaping the capacities of 'Community' and 'Environment'. Geoforum 75: 1-11. https:// doi.org/10.1016/j.geoforum.2016.06.014.

Boucquey, Noëlle, Kevin St Martin, Luke Fairbanks, Lisa M. Campbell, and Sarah Wise. 2019. Ocean data portals: Performing a new infrastructure for ocean governance. Environment and Planning D: Society and Space 37: 484-503. https://doi.org/10.1177/02637 75818822829.

Brattland, Camilla. 2014. A cybernetic future for small-scale fisheries. Maritime Studies 13: 1-21.

Brennan, Ruth. Forthcoming. Fishing for survival in the 'blue economy'- Found poems from the Irish islands. ACME An International Journal for Critical Geographies

Brennan, Ruth. 2019. Critical reflections on 21 November 2019 Dáil Eireann debate on the Island Fisheries (Heritage Licence) Bill. https://doi.org/10.5281/ZENODO.4064047.

Brennan, Ruth, and Michael (Mysh) Rozanov. 2020. Managing for Diversity: Keeping everyone afloat in Irish fisheries. Vimeo. Video, 6:47. https://vimeo.com/481200883 Accessed 11.7.21

Brent, Zoe W, Mads Barbesgaard, and Carsten Pedersen. 2018. The blue fix: Unmasking the politics behind the promise of blue growth ideas into movement. https://www.tni.org/files/publi cation-downloads/the_blue_fix_english.pdf Accessed 11.7.21

Bresnihan, Patrick. 2016. Transforming the fisheries: Neoliberalism, nature, and the commons. Lincoln: University of Nebraska Press.

Bresnihan, Patrick. 2019. Revisiting neoliberalism in the oceans: Governmentality and the biopolitics of 'improvement' in the Irish and European fisheries. Environment and Planning A: Economy and Space 51: 156-177. https://doi.org/10.1177/0308518X18803110.

Burman, Anders. 2017. The political ontology of climate change: moral meteorology, climate justice, and the coloniality of reality in the Bolivian Andes. Journal of Political Ecology 24: 921-930. https:// doi.org/10.2458/v24i1.20974.

Carpenter, Griffin and Richard Kleinjans. 2017. Who Gets to Fish? The allocation of fishing opportunities in EU member states. London: New Economics Foundation. https://neweconomics.org/uploads/ files/Carpenter-Kleinjans-Who-gets-to-fish-16.03.pdf Accessed 6.12 .21

Charmaz, Kathy. 2006. Constructing grounded theory: A practical guide through qualitative analysis. London: Sage.

DAFM. 2016. Fisheries quota management in Ireland. https://www. agriculture.gov.ie/seafood/seafoodpolicy/forms/ Accessed 11.7.21

DAFM. 2018a. Annual Report to the European Commission on the Irish Fishing Fleet for 2018. https://ec.europa.eu/oceans-and-fishe ries/system/files/2019-09/2018-fleet-capacity-report-ireland_en. pdf Accessed 18 January 2022

DAFM. 2018b. Consultation paper on minister's review of trawling activity inside the 6 nautical mile zone. https://irishelasmobran chgroup.files.wordpress.com/2018/09/consultation-6-nauticalmile.pdf Accessed 18 January 2022

DAFM. 2019. The Quota Management Advisory Committee. https:// assets.gov.ie/98546/4ada4299-b5c2-443e-aabc-1cdcf0ff1d49.pdf. Accessed 18 Jan 2022

DAFM. 2020. Overview of sea fishing boat licensing and registration. https://www.gov.ie/en/publication/6b108-amended-sea-fishi ng-boat-licence-application-form-and-notes/ Accessed 6.12.21.

DAFM. 2021. Press Release. McConalogue announces recognition of IIMRO as a seafood producer organisation. https://www.gov. ie/en/press-release/1d318-mcconalogue-announces-recognitionof-iimro-as-a-seafood-producer-organisation/ Accessed 6.12.21.

Daniels, Jennifer, and Charles Mather. 2017. Conservation and care: Material politics and Atlantic salmon on Newfoundland's Gander River. Maritime Studies 16: 1-17.

DePuy, Walker, Jacob Weger, Katie Foster, Anya M. Bonanno, Suneel Kumar, Kristen Lear, Raul Basilio, and Laura German. 2021. Environmental governance: Broadening ontological spaces for a more livable world. Environment and Planning E: Nature and Space. SAGE Publications: 251484862110185. https://doi.org/10. $1177 / 25148486211018565$. 
Donkersloot, Rachel, and Charles Menzies. 2015. Place-based fishing livelihoods and the global ocean: The Irish pelagic fleet at home and abroad. Maritime Studies 14: 20. https://doi.org/10.1186/ s40152-015-0038-5.

Fahy, Edward. 2013. Overkill!: The euphoric rush to industrialise Ireland's sea fisheries and its unravelling sequel. Edward Fahy.

Fairbanks, Luke, Lisa M. Campbell, Noëlle Boucquey, and Kevin St. Martin. 2018. Assembling enclosure: Reading marine spatial planning for alternatives. Annals of the American Association of Geographers 108: 144-161. https://doi.org/10.1080/24694 452.2017.1345611.

FAO. 2021. Fisheries technology. http://www.fao.org/fishery/techn ology/en Accessed 11.7.21

Fitzpatrick, Mike, Ruth Brennan, and Emmet Jackson. 2020. From Protest to Participation: Learning from experience in Irish inshore fisheries management. In Small-scale fisheries in Europe: Status, resilience and governance, ed. José J. PascualFernández, Cristina Pita, and Maarten Bavinck, 307-327. Cham: Springer International Publishing. https://doi.org/10. 1007/978-3-030-37371-9_15.

Flyvbjerg, Bent, Todd Landman, and Sanford Schram. 2012. Real social science: Applied phronesis. Real social science: Applied phronesis. Cambridge: Cambridge University Press. https://doi. org/10.1017/CBO9780511719912.

Flyvbjerg, Bent, Todd Landman, and Sanford Schram. (2016). Tension points: Learning to make social science matter. Critical Policy Studies. https://papers.ssrn.com/sol3/papers.cfm?abstract_id= 2721321 Accessed 18 Jan 2022

Frangoudes, Katia, and Manuel Bellanger. 2017. Fishers' opinions on marketization of property rights and the quota system in France. Marine Policy 80: 107-112.

Glaser, Barney G., and Anselm L. Strauss. 1967. The discovery of grounded theory. strategies for qualitative research. New Brunswick: AldineTransaction.

Holm, Petter and Kåre Nolde Nielsen. 2004. The TAC machine. In Report of the working group on fishery systems, WGFS Annual Report, 40-51. Copenhagen: ICES. https://www.ices.dk/sites/pub/ Publication\%20Reports/Expert\%20Group\%20Report/rmc/2004/ wgfs/wgfs04.pdf Accessed 6.12.21.

Johnsen, Jahn P. 2014. Is fisheries governance possible? Fish and fisheries 15: 428-444.

Johnsen, Jahn Petter. 2017. Creating political spaces at sea-governmentalisation and governability in Norwegian fisheries. Maritime Studies 16: 1-24.

Johnsen, Jahn Petter. 2020. Small-scale fisheries governance in Norway: Hierarchy, institutions and markets. In Small-Scale Fisheries in Europe: Status, Resilience and Governance, ed. José J. Pascual-Fernández, Cristina Pita, and Maarten Bavinck, 439-461. Cham: Springer International Publishing. https://doi.org/10.1007/ 978-3-030-37371-9_21.

Kelly, Christina, Geraint Ellis, and Wesley Flannery. 2019. Unravelling persistent problems to transformative marine governance. Frontiers in Marine Science 6: 213. https://doi.org/10.3389/fmars. 2019.00213

Lakoff, George. 2010. Why it matters how we frame the environment. Environmental Communication 4: 70-81. https://doi.org/10.1080/ 17524030903529749

Law, John. 2011. Whats wrong with a one-world world. Heterogeneities. net.

Law, John, and Marianne Elisabeth Lien. 2013. Slippery: Field notes in empirical ontology. Social studies of science 43: 363-378.

Linke, Sebastian, and Svein Jentoft. 2014. Exploring the phronetic dimension of stakeholders' knowledge in EU fisheries governance. Marine policy 47: 153-161.
St. Martin, Kevin. 2006. The impact of "community" on fisheries management in the US Northeast. Geoforum 37: 169-184. https://doi. org/10.1016/j.geoforum.2005.05.004.

St. Martin, Kevin, and Julia Olson. 2017. Creating space for community in marine conservation and management: Mapping "communities-at-sea". In Conservation for the Anthropocene Ocean: Interdisciplinary Science in Support of Nature and People, ed. Phillip S. Levin and M. Poe, 123-141. New York: Elsevier. https:// doi.org/10.1016/B978-0-12-805375-1.00007-6.

St. Martin, Kevin, Gerda Roelvink, and J.K. Gibson-Graham. 2015. Introduction: An economic politics for our times. In Making other worlds possible: Performing diverse economies, ed. Gerda Roelvink, Kevin St. Martin, and J.K. Gibson-Graham, 1-25. Minnesota: University of Minnesota Press.

Mather, Charles, Jahn Petter Johnsen, Signe Sønvisen, Aarthi Sridhar, and Johny Stephen. 2017. Introduction to the themed issuepoststructural approaches to fisheries. Maritime Studies 16: 1-15.

McCormack, Fiona. 2016. Quota systems: Repositioning value in New Zealand, Icelandic and Irish fisheries. Anthropologies of Value: 175-197.

McCormack, Fiona. 2017. Private oceans: The enclosure and marketisation of the seas. London: Pluto Press.

McCormack, Fiona, and Jacinta Forde. 2020. Fishing. In Encyclopedia of Anthropology, ed. Oxford Research, 1-39. Oxford: Oxford University Press. https://doi.org/10.1093/acrefore/9780190854 584.013.183.

Mol, Annemarie. 1999. Ontological politics. A word and some questions. The sociological review 47: 74-89.

Mol, Annemarie. 2002. The body multiple: Ontology in medical practice. Durham: Duke University Press.

Neilson, Alison Laurie, and Rita São Marcos. 2019. Reframing marine resource management with relational ontologies and hybrid entanglements: Fishing for empathy between Azorean fishers and scientists. Marine Policy 105: 30-37. https://doi.org/10.1016/J. MARPOL.2019.04.004.

Nightingale, Andrea. 2013. Fishing for nature: The politics of subjectivity and emotion in Scottish inshore fisheries management. Environment and Planning A 45: 2362-2378. https://doi.org/10. 1068/a45340.

Nightingale, Andrea J. 2011. Beyond design principles: Subjectivity, emotion, and the (Ir)rational commons. Society and Natural Resources 24: 119-132. https://doi.org/10.1080/0894192090 3278160.

Oireachtas. 2020. Fishing industry, Dáil Éireann debate, questions. Thursday 20 July 2020. https://www.oireachtas.ie/en/debates/ question/2020-09-17/228/ Accessed 11.7.21

Olson, Julia. 2010. Seeding nature, ceding culture: redefining the boundaries of the marine commons through spatial management and GIS. Geoforum 41: 293-303.

Olson, Julia. 2011. Producing nature and enacting difference in ecosystem-based fisheries management: An example from the Northeastern US. Marine Policy 35: 528-535.

Pascual-Fernández, José J., Cristina Pita, and Maarten Bavinck. 2020. Small-scale fisheries take centre-stage in Europe (Once Again). In Small-scale fisheries in Europe: Status, resilience and governance, ed. José J. Pascual-Fernández, Cristina Pita, and Maarten Bavinck, 1-22. Cham: Springer International Publishing.

Pascual-Fernández, José J., Cristina Pita, Helga Josupeit, Alicia Said, and João Garcia Rodrigues. 2019. Markets, distribution and value chains in small-scale fisheries: A special focus on Europe. In Transdisciplinarity for Small-Scale Fisheries Governance, ed. Ratana Chuenpagdee and Svein Jentoft, 141-162. Cham: Springer International Publishing.

Percy, Jeremy, and Brian O'Riordan. 2020. The EU Common fisheries policy and small-scale fisheries: A forgotten fleet fighting for recognition. In Small-scale fisheries in Europe: Status, resilience 
and governance, ed. José J. Pascual-Fernández, Cristina Pita, and Maarten Bavinck, 23-46. Cham: Springer International Publishing.

Rossiter, Jaime Speed, Giorgio Hadi Curti, Christopher M. Moreno, and David Lopéz-Carr. 2015. Marine-space assemblages: Towards a different praxis of fisheries policy and management. Applied Geography 59: 142-149.

Schwach, Vera, Denis Bailly, Anne-Sofie Christensen, Alyne E. Delaney, Poul Degnbol, L.T. van Densen Wim, Petter Holm, et al. 2007. Policy and knowledge in fisheries management: A policy briefa. ICES Journal of Marine Science 64: 798-803. https://doi. org/10.1093/icesjms/fsm020.

Snyder, Robert, and Kevin St Martin. 2015. A fishery for the future: The midcoast fishermen's association and the work of economic being-in-common. In Making other worlds possible: Performing diverse economies, ed. G. Roelvink, K. St. Martin, and J.K. Gibson-Graham, 26-52. Minneapolis: University of Minnesota.

Sønvisen, Signe Annie, Trine M. Thorvaldsen, and Jahn Petter Johnsen. 2017. Governing the fisher body-safety as body-politics and fisheries governance. Maritime Studies 16: 1-20.

Sullivan, Sian. 2017. What's ontology got to do with it? On nature and knowledge in a political ecology of the'green economy'. Journal of Political Ecology 24: 217-242.
Urquhart, Julie, Tim Acott, and Minghua Zhao. 2013. Introduction: Social and cultural impacts of marine fisheries. Marine Policy 37: 1-2. https://doi.org/10.1016/j.marpol.2012.04.007.

Williams, Daniel R. 2014. Making sense of 'place': Reflections on pluralism and positionality in place research. Landscape and Urban Planning 131: 74-82.

Williams, Daniel R. 2018. Spacing conservation practice: Place-making, social learning, and adaptive governance in natural resource management. In The SAGE Handbook of Nature, ed. Terry Marsden, 285-303. London: SAGE. https://doi.org/10.4135/97814 73983007.n16.

Yates, Julian S., Leila M. Harris, and Nicole J. Wilson. 2017. Multiple ontologies of water: Politics, conflict and implications for governance. Vol. 35, 797-815. London, England: Environment and Planning D: Society and Space.

Publisher's note Springer Nature remains neutral with regard to jurisdictional claims in published maps and institutional affiliations. 